\title{
Aile Üyelerinin Aile İletişim Kalıpları Algıları Arasındaki İlişki
}

\author{
Ömer Erdoğan (Dr.) \\ Kastamonu Üniversitesi Fen-Edebiyat Fakültesi \\ oerdogan@kastamonu.edu.tr \\ ORCID: 0000-0003-2138-3066
}

Başvuru Tarihi: 20.09.2019

Yayına Kabul Tarihi: 08.10.2019

Yayınlanma Tarihi: 24.01.2020

DOI: http://10.17680/erciyesiletisim.622576

\section{Öz}

Aile iletişimi açıkça farkedilebilir kalıplar ve formlarla karakterize edilir. Aileleri birbirinden ayıran ve iletişimsel davranışlarla ilișkilendirilen iki temel boyut, diyalog yönelimi ve uyum yönelimidir. Diyalog yönelimi, tüm aile üyelerinin çok çeşitli konular hakkında sınırsız etkileşimlere katılmaya teşvik edildiği bir iklim yaratma derecesi olarak tanımlanmaktadır. Uyum yönelimi ise, aile iletişiminin tutum, değer ve inançların homojenliği iklimini ne derece vurguladığını ifade eder. Bu kapsamda, yapılan çalışmada Ritchie ve Fitzpatrick'in (1990) Gözden Geçirilmiş Aile İletişimi Kalıpları Ölçeği kullanılarak üç temel konu incelenmiştir: ilk olarak, aile üyelerinin diyalog yönelimi ve uyum yönelimi boyutlarını, algılamaları arasındaki ilişki; ikincisi, ebeveynlerin köken aileleri ve şimdiki aile iletişim şekilleri algısı arasındaki ilişki; üçüncü olarak köken aile türlerinin mevcut aile türlerine nasıl yansıdığı. Çalışmanın verileri anket uygulaması ile toplanmış olup, 2018-2019 yılları arasında 176 aileden toplam 704 katılımcı çalışmaya katılmıştır. Bu çalışmada aile üyelerinin iki boyutu (diyalog yönelimi ve uyum yönelimi) algıları arasında güçlü bir ilişki olduğu ve aynı zamanda aile üyeleri, farklı aile türlerini benzer şekilde tanımladıkları ve son olarak, çiftler benzer bir aile tipinden geliyorsa, mevcut aile tiplerinin büyük ölçüde aynı şekilde muhafaza edildiği bulunmuştur. Elde edilen sonuçlar birlikte değerlendirildiğinde çocukluk dönemi iletişim kalıplarının ilerleyen yaş dönemlerine aktarıldığı görülmektedir.

Anahtar Kelimeler: Aile İletişim Kalıpları, Aile İletişimi, Uyum Yönelimi, Diyalog Yönelimi. 


\title{
Relationship Between Family Members' Perceptions of Family Communication Pattern
}

\author{
Ömer Erdoğan (Ph.D.) \\ Kastamonu University Faculty of Science and Literature \\ oerdogan@kastamonu.edu.tr \\ ORCID: 0000-0003-2138-3066
}

Date Received: 20.09.2019

Date Accepted: 08.10.2019

Date Published: 24.01.2020

DOI: http://10.17680/erciyesiletisim.622576

\begin{abstract}
Family communication is characterized by clearly recognizable patterns and forms. Two fundamental dimensions that both distinguish how families communicate and that have been associated with various functional consequences for families are conversation orientation and conformity orientation (Ritchie \& Fitzpatrick, 1990). Conversation Orientation is defined as the degree to which families create a climate in which all family members are encouraged to participate in unrestrained interactions about a wide array of topics. In this context, in this study, Ritchie's and Fitzpatrick's (1990) Revised Family Communication Patterns Scale was used to examine three main topics: first, the relationship between family members' perceptions of conversation orientation and conformity orientation dimensions; secondly, the relationship between parents' perception of their origin families and current family communication patterns; and third, how the origin family species are reflected in the existing family species. The data of the study were collected through a survey and a total of 704 participants from 176 families participated in the study in 2018-2019. In this study, it is evident that there is a strong relationship between the family members' perceptions of the two dimensions, and also family members define different family types in a similar way and then, the existing family types were maintained in the same way in the current family if the couples are coming from a similar family type. When the results obtained are evaluated together, it is seen that childhood communication patterns are transferred to later age periods.
\end{abstract}

Keywords: Family Communication Patterns, Family Communication, Conformity Dimension, Conversation Dimension. 


\section{Giriş}

Tamamının olmasa da aile iletişimi üzerine çalışan çoğu bilim insanının, sistem teorisine dayanan bir dünya görüşü vardır. İletişim alanında bu dünya görüşü genellikle, etkileşimsel yaklaşım ve pragmatik (yararcı) yaklaşımdan biri veya her ikisiyle birleștirilir. Aileye etkileşim temelindeki bir yaklaşım, bireyleri aile üyeleri olarak birbirine bağlayan iletişim süreçlerine odaklanarak, iletişimin aileyi nasıl oluşturduğunu anlamaya çalışır. Aile iletişim yaklaşımını benimseyen bilim adamları, etkileşim yoluyla ilişkilerin kurulmasının, aile üyelerinin kendi iletişimleriyle aile kimliğini yaratması ve sürdürmesi nedeniyle bir ailenin toplumsal gerçekliğini oluşturma sürecindeki yerinin merkezi olduğunu düşünürler. İlişkisel tanımlardan ilki Burgess ve Locken'ın (1953) iletişimi aile işlevinin merkezine yerleştirerek, aileyi "sadece üyelerin bir toplamı değil" yaşayan, değişen ve büyümekte olan "etkileşim yaşayan kişilerin birliği" (s. 5) olarak belirlemesiyle yapılmıştır. $\mathrm{Bu}$ yaklaşıma göre, bir grup insanı aile yapan temel unsur, görevlerini belirli bir iletişim ve etkileşim sistemi içinde yerine getirmeleridir (Segrin ve Flora, 2005, s. 10). İletişim, bireylerin anlam yarattığı, paylaştığı ve düzenlediği ilişkisel bir süreç (Segrin ve Flora, 2005, s. 15) olarak ele alındığında, aileler benzersiz birer mini kültür olarak (Whitchurch ve Dickson, 1999, s. 688) kendi sembolik anlam dünyalarını yaratırlar ve bu anlam dünyası yalnızca o kültürün parçaları tarafından anlaşılır. Çünkü her ailenin iletişimi, benzersiz bir tarih, şimdi ve gelecekle süreklidir. Dolayısıyla ailedeki geçmiş deneyimler, mevcut etkileşimleri açıkça etkileyerek, ailenin mevcut gerçekliğini tanımlar ve aile ilişsilerini kurar (Segrin ve Flora, 2005, s. 16).

İnsan sistemlerinde iletişim, yalnızca bilginin gerçek içeriğinin değişimi veya etkileşimdeki belirsizliğin azaltılmasından çok daha karmaşıktır; bunun nedeni, insanların çeşitli sistem seviyelerindeki eylemlerinin sosyal olarak yapısal gerçekliğine dayanıyor olmasıdır (Whitchurch ve Constantine, 1993). Aileye açık ve devam eden bir sistem olarak yaklaşım (Broderick, 1993, s. 40), ailenin iletişim kalıpları hakkında değerli bilgiler sağlar. Çünkü aileler sosyal gerçekliğini iletişim üzerinden yaratır ve üyelerinin ortak eylemleri, ailenin benzersiz ilişkilerine yansıyan özel ilişkisel gerçekliklerin gelişimine katkıda bulunarak, iletişim kalıplarının oluşumunu sağlar. Baxter ve Braithwaite'e (2002, s. 94) göre, aileler iletişimsel uygulamalar sayesinde kim olduğuyla ilgili toplumsal gerçekliğini ve onu düzenleyen anlamları inşa ederler. Her ne kadar eylemlerin koordinasyonu aile sistemleri arasında çarpıcı biçimde değișse de, açık ve devam eden sistemlerin bileșenleri arasındaki ilişkileri düzenleme özelliğinden dolayı her aile sistemi, hayatı bir şekilde öngörülebilir kılan iletişim kalıpları geliştirir. Shotter (1993), iletişim ve gerçeklik deneyimi arasındaki bu ilişkiyi bir döngü olarak karakterize eder: Ailedeki iletişim faaliyetleri, gerçeklerin aile üyeleri için nasıl deneyimlendiğini belirler ve gerçeklik deneyimi aile içindeki iletişim kalıplarını etkiler. İletișim süreciyle oluşturulan bu kalıplar öngörülebilirliği beraberinde getirir ve en azından bir dereceye kadar tahmin edilebilirlik, ailenin bir istikrar düzeyinde çalışmasına izin verir (Galvin, Bylund ve Brommel, 2016, s. 80).

Aile iletişim kalıplarına ilişkin öncü çalışmalar Wisconsin Üniversitesi'nde kitle iletişimi alanında çalışan, McLeod ve Chaffee'nin (1972, 1973), ailelerin ve çocuklarının harici bilgileri (özellikle de kitle iletişim araçları mesajı şeklinde gelen bilgiler) nasıl işlediğini açıklamak için yaptıkları çalışmalarda kullanmak için geliştirdikleri Aile İletişim Kalıpları (FCP) Ölçeğini geliştirmesine dayandırılır. Başlangıçta kitle iletişim araştırmaları için tasarlanan bu ölçek, aile iletişim yapısını belirleyen iki genel boyutu tanımlar: (a) uyumlu kişilerarası ilişkilerin sürdürülmesini vurgulayan sosyo-yönelim ve (b) açık, tartışmalı iletişime değer veren ve başkalarına katılmasalar bile çocukları fikirlerini ifade 
etmeye teşvik eden kavram-yönelimi. Bu araştırmacılar, toplumun iletişim modellerini şekillendirmede aile etkileşiminin önemini kabul etmelerine rağmen, Ritchie (1991), McLeod ve Chaffee'nin (1972) çerçevesine aykırı bir dizi araştırma bulgusunu belgelemiş ve sosyo-yönelimi ve kavram-yönelimi boyutlarını sırasıyla uyum-yönelimi ve diyalogyönelimi boyutları olarak yeniden yorumlamıştır.

Diyalog yönelimi boyutu, ailelerin, tüm aile üyelerinin çok çeşitli konular hakkında sınırsız etkileşime girmenin, yaşanılan çatışmalarla yüzleşmenin ve aynı zamanda ebeveynlerin evliliklerinde açık paylaşımın, bağımsızlığın ve özerkliğin teşvik edildiği bir iklim yaratma derecesi olarak tanımlanır. Uyum yönelimi boyutu ise, aile iletişiminde tutum, değer ve inançların homojenliğini vurgulama derecesini belirtir (Fitzpatrick ve Ritchie, 1994, s. 296-297). Ailelerin iletişimiyle ilgili bu iki temel boyutun gerçek aile iletişimi üzerindeki etkileri genellikle birbirine bağlıdır. Yani, aile iletişimi üzerinde ana etkilerinin olmasından ziyade, bu iki boyut genellikle birbirleri ile etkileşim halindedir. Dolayısıyla, bir boyutun aile iletişimi üzerinde nasıl bir etkiye sahip olduğunu tahmin etmek için yalnızca bu boyutu bilmek yeterli değildir, diğer boyutun bilinmesi de gereklidir. Örneğin, bir ailenin iletişim kalıplarını tahmin etmek için, bu ailenin uyum yönelimi boyutunda yüksek puan aldığını bilmek yeterli değildir, çünkü bunun aile iletişimi üzerindeki etkisi, o ailenin diyalog yönelimine ve bunun tam tersine bağlıdır (Koerner ve Fitzpatrick, 1997, s. 60).

Aile iletişimi üzerinde doğrudan etkilere sahip olmanın yanı sıra, uyum ve diyalog yönelimi boyutları birbirleriyle etkileşime girerek birbirlerinden niteliksel olarak farklı dört aile türü oluşturur. Fitzpatrick ve Ritchie'nin (1994) yapmış oldukları sınıflandırmaya göre, hem diyalog yönelimi hem de uyum yönelimi boyutlarından yüksek puan alan aileler fikir birliğine dayalı aileler olarak adlandırılmıștır. Bu ailelerin iletişim şekli, bir tarafta mevcut hiyerarşiyi kabul etmeye ve korumaya yönelik bir baskı ile diğer yandan açık iletişim ve yeni fikirleri keşfetme arasında bir gerilim ile karakterize edilir. Diyalog yönelimi boyutundan yüksek puan alan ancak uyum yönelimi boyutunda düșük puan alan aileler çoğulcu aileler olarak adlandırılmıştır. Çoğulcu ailelerde iletişim, açık ve sınırsız tartışmalarla karakterize edilir ve bu tartışmalar tüm aile üyelerine açıtır. Bu ailelerdeki ebeveynler, çocuklarının kontrolleri altında olmasına ya da onlar adına tüm kararları vermeye ihtiyaç duymazlar. Diyalog yönelimi boyutundan düşük puan alan ancak uyum yönelimi boyutundan yüksek puan alan aileler koruyucu aileler olarak adlandırılmıștır. Koruyucu ailelerdeki iletişim, ebeveyn otoritesine itaat ve kavramsal konularda veya aile içinde açık iletişim için az bir endișe ile vurgulanır. Hem diyalog yönelimi boyutunda hem de uyum yönelimi boyutunda düşük puan alan aileler ise, serbestiyetçi aileler olarak kavramlaştırılmıştır. Bu ailelerin iletişimleri, çoğunlukla sınırlı sayıda konuyu ilgilendiren, aile üyeleri arasında az sayıda ve genellikle etkilenmeyen etkileşimlerle karakterizedir.

İşleyen sosyal sistemler olarak varlıklarını sürdürebilmeleri için ailelerin ortak bir toplumsal gerçeklik yaratmaları ve davranışlarının çoğunu koordine etmesi gerekir. Bu onların nasıl davrandıkları ve iletişim kurdukları konusunda birbirleri hakkında makul ölçüde doğru tahminler yapmalarını gerektirir. Aile üyelerinin, başkalarının davranışlarını ve kendi davranışlarına verdikleri tepkileri tahmin etme yeteneği olmadan, aile işlevini yerine getiremez (Koerner, Fitzpatrick, 2004, s. 182). Bu da aile üyelerinin mevcut aile iletişim kalıplarını algılamalarına yönelik bir yakınlaşmayı zorunlu kılmaktadır. Aile iletişim kalıplarının yanlış algılanması üyeler arasındaki eşgüdümün sağlıklı işlememesine ve yanlış anlamalar sonucunda işlevsel olmayan davranışların görülmesine neden olabilir. Ailelerdeki yanlış anlamalar ve yanlış anlamalardan kaynaklanan sorunlar 
ailelerin sosyal gerçekliklerini ne kadar iyi paylaştığının doğrudan bir sonucu olduğunu gösterir (Koerner ve Fitzpatrick, 2002). Yani, aile üyelerinin sosyal ortamlarındaki diğer üyelerin sosyal gerçekliklerinden çok farklı bir sosyal gerçekliği paylaşması durumunda, aileler sosyopatolojileri deneyimleyebilir veya bireysel üyelerin psikopatolojilerine katkıda bulunabilir (Reiss, 1981).

Son araştırmalar (Ritchie ve Fitzpatrick, 1990), aile üyelerinin aile iletişim kalıpları ölçeğine vermiş oldukları yanıtlar arasındaki anlaşma ve anlaşmazlık şeklindeki teorik olarak ilginç yapının kanıtlarını ortaya koymasına rağmen, aile iletişim kalıbı araştırmacıları aracı nadiren aynı ailenin birden fazla üyesine uygulamıșlardır. Sheinkopf (1971) buna ilişkin, bir ailedeki farklı ebeveynlerin farklı yönelimleri vurgulayabileceğini ve bir çocuğun aynı aile içindeki diğer çocuklardan farklı şekilde davranabileceğini belirtmiştir. Bu tür bir değişimin ailelerde var olduğu ölçüde, aile iletişim modellerinin çocukların sosyalleşmesi ve gelişmesi üzerindeki potansiyel etkisinin tüm yaş seviyelerinde eşdeğer olamayabileceği iddia edilebilir. İletişim yönelimlerinin ebeveyn tarafından çocuğa iletildiğini varsaysak bile, ebeveynin davranışı çocuğun davranışı tarafından tetiklenebilir. Bu kapsamda çalıșmanın amacı aile iletişim araştırmalarının yedi varsayımını esas alarak (iliş̧iler etkileşim yoluyla oluşturulur; aile etkileşen bir sistemdir; aileler, aile yaşam döngüsü boyunca diyalektik gerilimleri sürekli yönetir ve müzakere eder; aileler, aile yaşam döngüsü boyunca iliş̧kisel tanımlarını yönetmeli ve yeniden görüşmelidir; aile birimlerinin iletişim tanımları aile birimlerinin yapısal tanımları üzerine önceliklidir; aile geçişlerinde iletişimi anlamak aile yaşam döngülerini anlamak için kritiktir; aileler kendi eşsiz mini kültürlerini yaratır ve korur) (Whitchurch ve Dickson, 1999, s. 693), aile üyelerinin, aile iletişim kalıplarını algılamaları arasındaki ilişki ve ebeveynlerin köken aileleri ile mevcut ailelerinin aile iletişim kalıplarını karşılaştırarak ortaya çıkan farklılaşmaların incelenmesidir.

\section{Hipotezler}

$\mathrm{Bu}$ çalışma aile iletişim kalıpları boyutlarının ebeveynler ve çocukları tarafından algılamaları arasındaki ilişkiyi ve ebeveynlerin geldikleri köken aile türüne bağlı olarak yeni kurdukları aile türünün nasıl șekillendiğini test etmek amacıyla düzenlenmiștir. Bu amaç doğrultusunda aşağıda belirtilen hipotezler test edilecektir:

H1: Çocukların diyalog yönelimleri ile ebeveynlerin diyalog yönelimleri arasında pozitif yönlü ilişki vardır.

H2: Çocukların uyum yönelimleriyle ebeveynlerin uyum yönelimleri arasında pozitif yönlü ilişki vardır.

H3: Eşlerin diyalog yönelimi arasında pozitif ilişki vardır.

H4: Eşlerin uyum yönelimi arasında pozitif ilişki vardır.

H5: Eşlerin köken aile diyalog yönelimi algılarıyla mevcut aile diyalog yönelimi algıları arasında pozitif ilişki vardır.

H6: Eşlerin köken aile uyum yönelimi algılarıyla mevcut aile uyum yönelimi algıları arasında pozitif ilişki vardır.

H7: Aynı tür köken aile türünden gelen çiftlerin mevcut aile türleri de aynıdır.

H8: Farklı aile türünden gelen çiftler ortak yeni bir aile türü oluşturmaktadır. 


\section{Yöntem}

\section{Örneklem:}

Çalışmaya 2018-2019 yıllarında toplam 176 ailede yer alan 704 katılımcı katılmıştır. Aileler anne, baba ve iki çocuktan oluşup bir arada yaşamaktadırlar. Katılımcı çiftler en az 15 yıllık evli olup tek evlilik yapmış çiftlerden seçilmiştir. Çalışmaya katılan çocukların yaşları en az 12'dir ve aileden ayrılmamış olup halen aileyle birlikte yaşamlarını sürdürmektedirler. Katılımcılar 2018-2019 yılı içerisinde Kastamonu Üniversitesinde eğitimlerine devam eden ve araștırmacının derslerine girdiği (PDR, Çocuk Gelişimi ve Felsefe bölümleri) öğrenciler arasından belirlenmiștir.

\section{Veri Toplama Araçları:}

\section{Aile İletişim Kalıbı Ölçeği (AikÖ)}

Katılımcıların aile iletişim kalıplarını belirlemeye yönelik olarak Ritchie ve Fitzpatrick (1990) tarafından revize edilen ve Türkçe geçerlilik güvenirlik çalışması Erdoğan ve Anık (2018) tarafından yapılan Revize Aile İletişim Kalıbı Ölçeği kullanılmıștır. Ölçek, aile üyeleri arasında vurgulanan uyum ve diyalog düzeylerini belirten iki boyuttan oluşmaktadır. AİKÖ 26 maddeden oluşmakta olup, diyalog yönelimi boyutu ilk 15 maddeyi (Ör. Hemen hemen her şeyi ebeveynlerime söyleyebilirdim) ve uyum yönelimi boyutu ise son 11 maddeyi (Ör. Ĕger görüşlerim ebeveynlerimden farklı ise bazen klzarlardı) içermektedir. Ölçek maddeleri, kesinlikle katılmıyorumdan (1) kesinlikle katılıyoruma (5) kadar değişen ve katılımcıların beyanına dayalı olarak cevap verdikleri 5 puanlı Likert yanıt formatı kullanılarak derecelendirilmiştir. Ölçek maddelerinin ifade şekli ebeveynlerin mevcut ailelerinin iletişim kalıplarını belirlemeye yönelik olarak maddelerin içeriğini değiştirmeden uygun şekilde ifade edilmiştir.

Ölçeğin puanlanmasında iki alt boyuttan alınan puanlar esas alınmaktadır. Diyalog yönelimi boyutunda katılımcının alabileceği en düşük puan 15 en yüksek puan 75; uyum yönelimi boyutunda ise katılımcının alabileceği en düşük puan 11, en yüksek puan ise 55'dir. Katılımcıların aile tiplerine dağıtılması her boyuttan alınan puanların ortalamasının belirlenmesi ile gerçekleştirilmektedir. Uyum boyutunun ortalamasının üzerinde puan alanlar yüksek, ortalamanın altında puan anlar ise düşük uyum düzeyinde yer alırken; diyalog yönelimi puanı ortalamasının üstünde yer alanlar yüksek, altında yer alanlar ise düşük diyalog yönelimli olarak adlandırılmaktadırlar. Buna göre hem uyum hem de diyalog yöneliminde yüksek grupta yer alanlar fikir birliğine dayalı ailelerde, hem uyum hem diyalog yöneliminde düşük grupta yer alanlar serbesiyetçi ailelerde, uyum yönelimi boyutunda yüksek diyalog yönelimi boyutunda düşük puan alan grupta yer alan katılımcılar koruyucu, diyalog yönelimi boyutundan yüksek uyum yönelimi boyutundan düşük puan alan katılımcılar ise çoğulcu ailelerde yer almaktadır.

\section{İşlem}

Çalışmanın amacı öğrencilere açıklanmış ve koşulları karşılayan ve gönüllü katılmayı kabul eden öğrencilere ölçeğin nasıl uygulanacağına dair bilgi verilmiştir. Ölçekler öğrencilerin şubat tatiline ailelerinin yanlarına gittikleri dönemde dağıtılmış ve öğrenciler tarafından ailelerine uygulanmıştır. Ailelerde yer alan çocuklar sadece AİKÖ'ni doldurmuşlar ebeveynler ise AİKÖ'ni hem mevcut ailelerini tanımlamak hem de köken ailelerini tanımlamak amacıyla iki sefer doldurmuşlardır. 


\section{Bulgular}

Çalışmanın amaçları doğrultusunda 2018-2019 yılları arasında toplam 704 (anne, baba ve iki çocuk) katılımcıya ölçek uygulaması gerçekleștirilmiş olup çalışmadan elde edilen bulgular aşağıda sunulmuştur.

Tablo 1: Frekans Tablosu Anne-baba

\begin{tabular}{|l|l|c|c|c|c|c|c|}
\hline \multirow{2}{*}{ Değişkenler } & \multicolumn{2}{|c|}{ Baba } & \multicolumn{2}{c|}{ Anne } & \multicolumn{2}{c|}{ Toplam } \\
\cline { 3 - 8 } & $34-39$ & $\mathbf{n}$ & $\mathbf{\%}$ & $\mathbf{n}$ & $\mathbf{\%}$ & $\mathbf{n}$ & $\%$ \\
\hline \multirow{5}{*}{ Yaş } & $40-45$ & 21 & 11.9 & 43 & 24.4 & 64 & 18.18 \\
\cline { 2 - 8 } & $46-51$ & 73 & 41.5 & 82 & 46.6 & 155 & 44.03 \\
\cline { 2 - 8 } & $52-57$ & 51 & 29.0 & 38 & 21.6 & 89 & 25.28 \\
\cline { 2 - 8 } & $58-63$ & 26 & 14.8 & 12 & 6.8 & 38 & 10.80 \\
\hline \multirow{4}{*}{ Eğitim Düzeyi } & İlkokul & 5 & 2.8 & 1 & 0.6 & 6 & 1.70 \\
\cline { 2 - 8 } & Ortaokul & 72 & 40.9 & 109 & 61.9 & 181 & 51.42 \\
\cline { 2 - 8 } & Lise & 31 & 17.6 & 21 & 11.9 & 52 & 14.77 \\
\cline { 2 - 8 } & Yüksekokul ve Üstü & 19 & 10.8 & 16 & 9.1 & 35 & 9.94 \\
\hline \multirow{2}{*}{ Toplam } & & 176 & 100 & 176 & 100 & 352 & 100 \\
\hline
\end{tabular}

Çalışmaya 176 baba ve 176 anne katılmış olup babaların yaş ortalaması $\overline{\mathrm{x}}=45.67$ annelerin yaş ortalaması ise $\overline{\mathrm{x}}=43.05$ 'dir. Babaların 21 (\%11.9) tanesi, annelerin ise 43 (\%24.4) tanesi 34-39 yaş aralığında yer alırken, babaların 73 (\%41.5) annelerin 82 (\%46.6) tanesi 40-45 yaş aralığında, babaların 51 (\%29.0) annelerin 38 (\%21.6) tanesi 46-51 yaș aralığında, babaların 26 (\%14.8) annelerin 12 (\%6.8) tanesi 52-57 yaş aralığında ve babaların 5 (\%2.8) ve annelerin ise $1(\% 0.6)$ tanesi 58-63 yaş aralığında yer almaktadır. Çalışmaya katılan babaların 72'si (\%40.9) annelerin ise 109'u (\%61.9) ilkokul mezunu, babaların 31'i (\%17.6) annelerin 21'i (\%11.9) ortaokul mezunu, babaların 54'ü (\%30.7) annelerin 30'u (\%17.1) lise ve babaların 19'u (\%10.8) annelerin ise 16'sı (\%9.1) yüksekokul ve üstü eğitim almıştır.

Tablo 2: Frekans Tablosu Çocuklar

\begin{tabular}{|c|c|c|c|c|c|c|c|}
\hline \multirow{2}{*}{\multicolumn{2}{|c|}{ Değişkenler }} & \multicolumn{2}{|c|}{ Birinci Çocuk } & \multicolumn{2}{|c|}{ İkinci Çocuk } & \multicolumn{2}{|c|}{ Toplam } \\
\hline & & $\mathbf{n}$ & $\%$ & $\mathbf{n}$ & $\%$ & $\mathbf{n}$ & $\%$ \\
\hline \multirow{2}{*}{ Cinsiyet } & Kadın & 104 & 59.1 & 93 & 52.8 & 197 & 55.97 \\
\hline & Erkek & 72 & 40.9 & 83 & 47.2 & 155 & 44.03 \\
\hline \multirow{4}{*}{ Yaş } & $12-16$ & 51 & 29.0 & 114 & 64.8 & 165 & 46.88 \\
\hline & $17-21$ & 82 & 46.6 & 57 & 32.4 & 139 & 39.49 \\
\hline & $22-26$ & 38 & 21.6 & 5 & 2.8 & 43 & 12.21 \\
\hline & $27-31$ & 5 & 2.8 & - & - & 5 & 1.42 \\
\hline \multirow{4}{*}{ Eğitim Düzeyi } & İlkokul & 8 & 4.5 & 29 & 16.5 & 37 & 10.51 \\
\hline & Ortaokul & 26 & 14.8 & 52 & 29.5 & 78 & 22.16 \\
\hline & Lise & 72 & 40.9 & 63 & 35.8 & 135 & 38.35 \\
\hline & Yüksekokul ve Üstü & 70 & 39.8 & 32 & 18.2 & 102 & 28.98 \\
\hline \multicolumn{2}{|l|}{ Toplam } & 176 & 100 & 176 & 100 & 352 & 100 \\
\hline
\end{tabular}

Çalışmaya katılan toplam 352 çocuğun 197'si (\%55.97) kadın 155'i (\%44.03) erkek olup birinci çocukların yaş ortalaması $\overline{\mathrm{x}}=18.95$ ikinci çocukların yaş ortalaması ise $\overline{\mathrm{x}}=15.58$ 'dir. Birinci çocukların 104'ü (\%59.1) kadın 72'si (\%40.9) ise erkek olup kadın katılımcıların 30'u (\%17.0) erkeklerin 21'i (\%11.9) 12-16 yaş aralığında yer alırken, kadınların 54 (\%30.7) erkeklerin 28 (\%15.9) tanesi 17-21 yaş aralığında, kadınların 18 (\%10.2) 
erkelerin 20 (\%11.4) tanesi 22-26 yaș aralığında ve kadınların 2 (\%1.1) erkeklerin ise 3 (\%1.7) tanesi 27-31 yaş aralığında yer almıştır. Birinci çocukların 8'i (\%4.5) ilkokul, 26'sı (\%14.8) ortaokul, 72'si (\%40.9) lise ve 70'i (\%39.8) ise yüksekokul ve üstü eğitim düzeyindedir. Çalışmaya katılan ikinci çocukların 93'ü (\%52.8) kadın 83'ü (\%47.2) ise erkek olup kadın katılımcıların 52 (\%29.5) erkek katılımcıların 62 (\%35.2) tanesi 12-16 yaş aralığında yer alırken kadınların 39 (\%22.2) erkeklerin 18 (\%10.2) tanesi 17-21 yaş aralığında ve kadınların 2 (\%1.1) erkeklerin ise 3 (\%1.7) tanesi 22-26 yaş aralığında yer almıştır. İkinci çocukların 29’u (\%16.5) ilkokul, 52'si (\%29.5) ortaokul, 63'ü (\%35.8) lise ve 32'si (\%18.2) yüksekokul ve üstü eğitim düzeyinde yer almıştır.

Tablo 3: Anne-Baba Aile Türü Algısı Tablosu

\begin{tabular}{|c|c|c|c|c|c|c|c|c|c|c|c|}
\hline & \multirow{3}{*}{ Aile Türü } & \multicolumn{8}{|c|}{ Aile Türü Algısı Anne } & \multirow{2}{*}{\multicolumn{2}{|c|}{ Toplam }} \\
\hline & & \multicolumn{2}{|c|}{ Çoğulcu } & \multicolumn{2}{|c|}{ Koruyucu } & \multicolumn{2}{|c|}{$\begin{array}{c}\text { Fikir Birliğine } \\
\text { Dayalı }\end{array}$} & \multicolumn{2}{|c|}{ Serbesiyetçi } & & \\
\hline & & $\mathbf{n}$ & $\%$ & $\mathbf{n}$ & $\%$ & $\mathbf{n}$ & $\%$ & $\mathbf{n}$ & $\%$ & $\mathbf{n}$ & $\%$ \\
\hline \multirow{4}{*}{$\begin{array}{l}\text { Aile } \\
\text { Türü } \\
\text { Algısı } \\
\text { Baba }\end{array}$} & Çoğulcu & 58 & 33,0 & 9 & 5,1 & 5 & 2,8 & 3 & 1,7 & 75 & 42,6 \\
\hline & Koruyucu & 7 & 4,0 & 34 & 19,3 & 6 & 3,4 & 4 & 2,3 & 51 & 29,0 \\
\hline & $\begin{array}{l}\text { Fikir Birliğine } \\
\text { Dayalı }\end{array}$ & 5 & 2,8 & 6 & 3,4 & 16 & 9,1 & 1 & 0,6 & 28 & 15,9 \\
\hline & Serbesiyetçi & 2 & 1,1 & 3 & 1,7 & 1 & 0,6 & 16 & 9,1 & 22 & 12,5 \\
\hline \multicolumn{2}{|c|}{ Toplam } & 72 & 40,9 & 52 & 29,5 & 28 & 15,9 & 24 & 13,6 & 176 & 100,0 \\
\hline
\end{tabular}

Çalışmaya katılan anne ve babaların aile türü algılarına bakıldığında (Tablo:3) annelerin 72'si (\%40.9) babaların ise 75'i (\%42.6) içinde bulundukları aileyi çoğulcu, annelerin 52'si (\%29.5) babalarin 51'i (\%29.0) koruyucu, annelerin 28'i (\%15.9) babalarin 28'i (\%15.9) fikir birliğine dayalı ve annelerin 24'ü (\%13.6) babaların ise 22'si (\%12.5) içinde bulundukları aileyi serbesiyetçi olarak tanımlamıştır. İçinde bulunduğu aile türünü çoğulcu olarak tanımlayan 72 annenin eşlerinden 58'i (\%80.55) benzer şekilde ailesini çoğulcu tanımlarken, aynı grupta yer alan 7 (\%9.72) baba eşlerinden farklı olarak aile türünü koruyucu, 5 (\%6.95) baba fikir birliğine dayalı ve 2 (\%2.78) baba ise serbesiyetçi olarak tanımlamıştır. İçinde bulunduğu aile türünü koruyucu olarak tanımlayan 52 annenin eşlerinden 34'ü (\%65.38) benzer şekilde ailesini koruyucu tanımlarken, aynı grupta yer alan 9 (\%17.30) baba eşlerinden farklı olarak aile türünü çoğulcu, 6 (\%11.54) baba fikir birliğine dayalı ve 3 (\%5.77) baba ise serbesiyetçi olarak tanımlamıştır. İçinde bulunduğu aile türünü fikir birliğine dayalı olarak tanımlayan 28 annenin eșlerinden 16'sı (\%17.14) benzer şekilde içinde yer aldığı aileyi fikir birliğine dayalı olarak tanımlarken, 5 (17.68) baba eşlerinden farklı olarak aile türünü çoğulcu, 6 (\%21.43) baba koruyucu ve 1(\%3.57) baba ise serbesiyetçi olarak tanımlamıştır. İçinde bulunduğu aile türünü serbesiyetçi olarak tanımlayan 24 annenin eşlerinden 16’sı (\%66.67) benzer şekilde içinde yer aldığı aileyi serbesiyetçi olarak tanımlarken 3 (\%12.5) baba eşlerinden farklı olarak aile türünü çoğulcu, 4 (\%16.67) baba koruyucu ve 1 (\%4.17) baba ise fikir birliğine dayalı olarak tanımlamıştır. 
Tablo 4: Cocukların Aile Türü Algısı Tablosu

\begin{tabular}{|c|c|c|c|c|c|c|c|c|c|c|c|}
\hline & \multirow{3}{*}{ Aile Türü } & \multicolumn{8}{|c|}{ Aile Türü Algısı İkinci Çocuk } & \multirow{2}{*}{\multicolumn{2}{|c|}{ Toplam }} \\
\hline & & \multicolumn{2}{|c|}{ Çoğulcu } & \multicolumn{2}{|c|}{ Koruyucu } & \multicolumn{2}{|c|}{$\begin{array}{c}\text { Fikir } \\
\text { Birliğine } \\
\text { Dayalı }\end{array}$} & \multicolumn{2}{|c|}{ Serbesiyetçi } & & \\
\hline & & $\mathbf{n}$ & $\%$ & $\mathbf{n}$ & $\%$ & $\mathbf{n}$ & $\%$ & $\mathbf{n}$ & $\%$ & $\mathbf{n}$ & $\%$ \\
\hline \multirow{4}{*}{$\begin{array}{l}\text { Aile } \\
\text { Türü } \\
\text { Algısı } \\
\text { Birinci } \\
\text { Çocuk }\end{array}$} & Çoğulcu & 52 & 29,5 & 6 & 3,4 & 3 & 1,7 & 3 & 1,7 & 64 & 36,4 \\
\hline & Koruyucu & 3 & 1,7 & 42 & 23,9 & 4 & 2,3 & 4 & 2,3 & 53 & 30,1 \\
\hline & $\begin{array}{l}\text { Fikir Birliğine } \\
\text { Dayalı }\end{array}$ & 8 & 4,5 & 4 & 2,3 & 25 & 14,2 & 4 & 2,3 & 41 & 23,3 \\
\hline & Serbesiyetçi & 3 & 1,7 & 6 & 3,4 & 0 & 0,0 & 9 & 5,1 & 18 & 10,2 \\
\hline \multicolumn{2}{|l|}{ Toplam } & 66 & 37,5 & 58 & 33,0 & 32 & 18,2 & 20 & 11,4 & 176 & 100,0 \\
\hline
\end{tabular}

Çalışmaya katılan çocukların aile türü algılarına bakıldığında (Tablo:4) birinci çocukların 64'ü (\%36.4) ikinci çocukların ise 66'sı (\%37.5) içinde bulunduğu aile türünü çoğulcu olarak tanımlarken, birinci çocukların 53'ü (\%30.1) ikinci çocukların 58'i (\%33.0) koruyucu, birinci çocukların 41'i (\%23.3) ikinci çocukların 32'si (\%18.2) fikir birliğine dayalı ve birinci çocukların 18'i (\%10.2) ikinci çocukların ise 20'si (\%11.4) içinde bulunduğu aileyi serbesiyetçi olarak tanımlamıştır. İçinde bulunduğu aile türünü çoğulcu olarak tanımlayan 64 birinci çocukla aynı grupta yer alan ikinci çocukların 52'si (\%81.25) ailesini benzer şekilde çoğulcu tanımlarken 6'sı (\%9.38) ailesini koruyucu, 3'ü (\%4.69) fikir birliğine dayalı ve 3'ü (\%4.69) ise serbesiyetçi olarak tanımlamıştır. İçinde bulunduğu aile türünü koruyucu olarak tanımlayan 53 birinci çocukla aynı grupta yer alan ikinci çocukların 42'si (\%79.25) ailesini benzer şekilde koruyucu tanımlarken 3'ü (\%5.66) ailesini çoğulcu, 4'ü (\%7.55) fikir birliğine dayalı ve 4'ü (\%7.55) ise serbesiyetçi olarak tanımlamıştır. İçinde bulunduğu aile türünü fikir birliğine dayalı olarak tanımlayan 41 birinci çocukla aynı grupta yer alan ikinci çocukların 25’i (\%60.98) ailesini benzer şekilde fikir birliğine dayalı tanımlarken 8'i (\%19.51) ailesini çoğulcu, 4'ü (\%9.76) koruyucu ve 4'ü (\%9.76) ise serbesiyetçi olarak tanımlamıştır. İçinde bulunduğu aile türünü serbesiyetçi olarak tanımlayan 18 birinci çocukla aynı grupta yer alan ikinci çocuğun 9'u (\%50.0) ailesini benzer şekilde serbesiyetçi tanımlarken 3'ü (\%16.67) ailesini çoğulcu ve 6'sı (\%33.33) ise koruyucu olarak tanımlamıştır.

Tablo 5: Baba Şimdi ve Köken Aile Türü Algısı

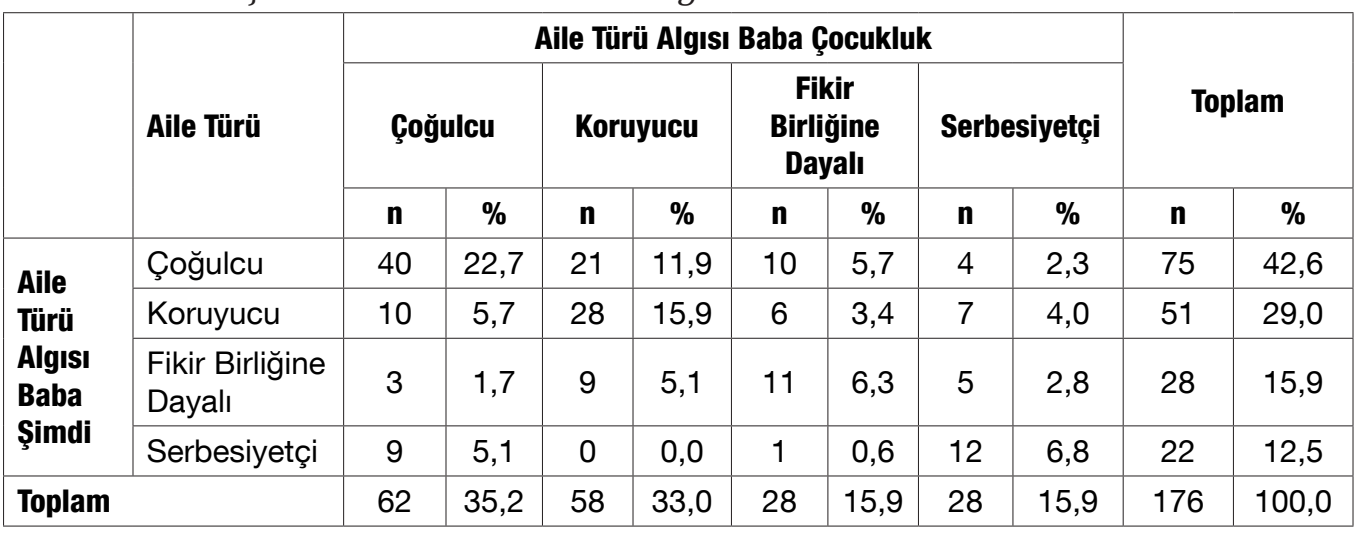

Babaların çocukluk dönemi aile türleriyle şu an içinde bulundukları aile türünün değerlendirildiği tablo 5 incelendiğinde, babaların 75'i (\%42.6) şu an içinde bulunduğu aile türünü çoğulcu olarak tanımlarken, 51'i (\%29.0) koruyucu, 28'i (\%15.9) fikir birliğine dayalı ve 22'si (\%12.5) ise serbesiyetçi olarak tanımlamıștır. Çocukluk dönemi içinde yaşadıkları aile türlerini tanımlarken ise babaların 62'si (\%35.2) ailesini çoğulcu, 58'i (\%33.0) koruyucu, 28'i (\%15.9) fikir birliğine dayalı ve 28'i (\%15.9) ise serbesiyetçi 
olarak tanımlamıştır. Şu an içinde bulunduğu aileyi çoğulcu olarak tanımlayan 75 babanın 40’ı (\%53.33) benzer şekilde çocukluk dönemi aile türünü de çoğulcu, 21'i (\%28.00) koruyucu, 10'u (\%13.33) fikir birliğine dayalı ve 4'ü (\%5.33) ise çocukluk dönemi aile türünü serbesiyetçi olarak tanımlamıştır. Şu an içinde bulunduğu aile türünü koruyucu olarak tanımlayan 51 babanın 28'i (\%54.90) benzer şekilde çocukluk dönemi aile türünü de koruyucu, 10’u (\%19.61) çoğulcu, 6’sı (\%11.76) fikir birliğine dayalı ve 7'si (\%13.73) ise çocukluk dönemi aile türünü serbesiyetçi olarak tanımlamıştır. Şu an içinde bulunduğu aileyi fikir birliğine dayalı olarak tanımlayan 28 babanın 11'i (\%39.29) benzer şekilde çocukluk dönemi aile türünü de fikir birliğine dayall, 3’ü (\%10.71) çoğulcu, 9’u (\%32.14) koruyucu ve 5’i (\%17.86) ise çocukluk dönemi aile türünü serbesiyetçi olarak tanımlamıştır. Şu an içinde bulunduğu aileyi serbesiyetçi olarak tanımlayan 22 babanın 12'si (\%54.55) benzer şekilde çocukluk dönemi aile türünü de serbesiyetçi, 9'u (\%40.91) çoğulcu ve 1'i (\%4.55) ise çocukluk dönemi aile türünü fikir birliğine dayalı olarak tanımlamıştır.

Tablo 6: Anne Şimdi ve Köken Aile Türü Algısı

\begin{tabular}{|c|c|c|c|c|c|c|c|c|c|c|c|}
\hline & \multirow{3}{*}{ Aile Türü } & \multicolumn{8}{|c|}{ Aile Türü Algısı Anne Çocukluk } & & \\
\hline & & \multicolumn{2}{|c|}{ Çoğulcu } & \multicolumn{2}{|c|}{ Koruyucu } & \multicolumn{2}{|c|}{$\begin{array}{c}\text { Fikir } \\
\text { Birliğine } \\
\text { Dayalı }\end{array}$} & \multicolumn{2}{|c|}{ Serbesiyetçi } & \multicolumn{2}{|c|}{ Toplam } \\
\hline & & $\mathbf{n}$ & $\%$ & $\mathbf{n}$ & $\%$ & $\mathbf{n}$ & $\%$ & $\mathbf{n}$ & $\%$ & $\mathbf{n}$ & $\%$ \\
\hline \multirow{4}{*}{$\begin{array}{l}\text { Aile } \\
\text { Türü } \\
\text { Algısı } \\
\text { Anne } \\
\text { Şimdi }\end{array}$} & Çoğulcu & 34 & 19,3 & 30 & 17,0 & 5 & 2,8 & 3 & 1,7 & 72 & 40,9 \\
\hline & Koruyucu & 8 & 4,5 & 30 & 17,0 & 7 & 4,0 & 7 & 4,0 & 52 & 29,5 \\
\hline & $\begin{array}{l}\text { Fikir } \\
\text { Birliğine } \\
\text { Dayalı }\end{array}$ & 9 & 5,1 & 12 & 6,8 & 7 & 4,0 & 0 & 0,0 & 28 & 15,9 \\
\hline & Serbesiyetçi & 8 & 4,5 & 5 & 2,8 & 2 & 1,1 & 9 & 5,1 & 24 & 13,6 \\
\hline \multicolumn{2}{|c|}{ Toplam } & 59 & 33,5 & 77 & 43,8 & 21 & 11,9 & 19 & 10,8 & 176 & 100,0 \\
\hline
\end{tabular}

Annelerin çocukluk dönemi aile türleriyle şu an içinde bulundukları aile türünün değerlendirildiği tablo 6 incelendiğinde, annelerin 72'si (\%40.9) şu an içinde bulunduğu aile türünü çoğulcu olarak tanımlarken, 52'si (\%29.5) koruyucu, 28'i (\%15.9) fikir birliğine dayalı ve 24'ü (\%13.6) ise serbesiyetçi olarak tanımlamıştır. Çocukluk dönemi içinde yaşadıkları aile türlerini tanımlarken ise annelerin 59'u (\%33.5) ailesini çoğulcu, 77'si (\%43.8) koruyucu, 21'i (\%11.9) fikir birliğine dayalı ve 19’u (\%10.8) ise serbesiyetçi olarak tanımlamıştır. Şu an içinde bulunduğu aileyi çoğulcu olarak tanımlayan 72 annenin 34'ü (\%47.22) benzer şekilde çocukluk dönemi aile türünü de çoğulcu, 30’u (\%41.67) koruyucu, 5'i (\%6.94) fikir birliğine dayalı ve 3'ü (\%4.17) ise çocukluk dönemi aile türünü serbesiyetçi olarak tanımlamıştır. Şu an içinde bulunduğu aileyi koruyucu olarak tanımlayan 52 annenin 30’u (\%57.69) benzer şekilde çocukluk dönemi aile türünü de koruyucu, 8'i (\%15.38) çoğulcu, 7'si (\%13.46) fikir birliğine dayalı ve 7'si (\%13.46) ise çocukluk dönemi aile türünü serbesiyetçi olarak tanımlamıştır. Şu an içinde bulunduğu aileyi fikir birliğine dayalı olarak tanımlayan 28 annenin 7'si (\%25.00) benzer şekilde çocukluk dönemi aile türünü de fikir birliğine dayalı, 9'u (\%32.14) çoğulcu ve 12'si (\%42.86) ise koruyucu olarak tanımlamıştır. Şu an içinde bulunduğu aileyi serbesiyetçi olarak tanımlayan 24 annenin 9'u (\%37.5) benzer şekilde çocukluk dönemi aile türünü de serbesiyetçi, 8'i (\%33.33) çoğulcu, 5’i (\%20.83) koruyucu ve 2'si (\%8.33) ise çocukluk dönemi aile türünü fikir birliğine dayalı olarak tanımlamıștır. 
Tablo 7: Anne-Baba ve Çocukların Aile Türü Algıları Kesişim Tablosu

\begin{tabular}{|c|c|c|c|c|c|c|c|c|}
\hline \multirow{3}{*}{\multicolumn{3}{|c|}{$\begin{array}{l}\text { A+B+Ç1+Ç2 } \\
\text { Aile Türü Algısı }\end{array}$}} & \multicolumn{4}{|c|}{ Ç1+Ç2 Aile Türü Algısı } & \multirow{2}{*}{\multicolumn{2}{|c|}{ Toplam }} \\
\hline & & & \multicolumn{2}{|c|}{0} & \multicolumn{2}{|c|}{1} & & \\
\hline & & & $\mathbf{n}$ & $\%$ & $n$ & $\%$ & $\mathbf{n}$ & $\%$ \\
\hline \multirow{3}{*}{$\mathbf{0}$} & \multirow{2}{*}{$A+B$} & 0 & 29 & 32,2 & 22 & 24,4 & 51 & 56,7 \\
\hline & & 1 & 18 & 20,0 & 21 & 23,3 & 39 & 43,3 \\
\hline & \multicolumn{2}{|c|}{ Toplam } & 47 & 52,2 & 43 & 47,8 & 90 & 100,0 \\
\hline \multirow{2}{*}{1} & $A+B$ & 1 & & & 86 & 100,0 & 86 & 100,0 \\
\hline & \multicolumn{2}{|c|}{ Toplam } & & & 86 & 100,0 & 86 & 100,0 \\
\hline \multirow{3}{*}{ Toplam } & \multirow{2}{*}{$A+B$} & 0 & 29 & 16,5 & 22 & 12,5 & 51 & 29,0 \\
\hline & & 1 & 18 & 10,2 & 107 & 60,8 & 125 & 71,0 \\
\hline & \multicolumn{2}{|c|}{ Toplam } & 47 & 26,7 & 129 & 73,3 & 176 & 100,0 \\
\hline
\end{tabular}

Anne, baba ve çocukların içinde bulundukları aile türünün birlikte değerlendirildiği tablo 7 incelendiğinde 86 (\%48.86) ailenin üyelerinin tamamı aile türünü belirlerken aynı türü belirlemiștir. Çalıșmaya katılan 125 (\%71.02) ailede yer alan anne ve babalar aile türünü aynı şekilde belirlerken, 129 (\%73.30) ailedeki çocuklar ise aile türünü aynı şekilde tanımlamıştır. Anne, baba ve çocukların ortak karara varamadığı 90 (\%51.14) ailenin 29'unda (\%16.48) hiçbir aile üyesi diğeriyle aynı aile türünü tanımlamamışken 39 (\%22.16) ailede yer alan anne ve babalar aynı 43 (\%24.43) ailede yer alan çocuklar ise aynı aile türünü tanımlamışlardır.

Tablo 8: Aile İletişim Kalıpları Ölçeği'nin Alt Boyutlarının Aile Üyeleri Algıları Arasındaki İlişkiler

\begin{tabular}{|c|c|c|c|c|c|c|c|c|}
\hline Boyutlar & $\begin{array}{c}\text { DY } \\
\text { 1.Çocuk }\end{array}$ & $\begin{array}{l}\text { UY } \\
\text { 1. Çocuk }\end{array}$ & $\begin{array}{c}\text { DY } \\
\text { 2.Çocuk }\end{array}$ & $\begin{array}{l}\text { UY } \\
\text { 2. Çocuk }\end{array}$ & $\begin{array}{c}\text { DY } \\
\text { Baba }\end{array}$ & $\begin{array}{c}\text { UY } \\
\text { Baba }\end{array}$ & $\begin{array}{c}\text { DY } \\
\text { Anne }\end{array}$ & $\begin{array}{c}\text { UY } \\
\text { Anne }\end{array}$ \\
\hline DY 1.Çocuk & 1 &,$- 228^{\star}$ &, $837^{\star \star}$ &,$- 264^{*}$ &, $710^{\star \star}$ &,$- 195^{\star}$ &, $725^{\star \star}$ &,$- 254^{\star}$ \\
\hline UY 1. Çocuk & & 1 &,- 127 & $807^{\star \star}$ &,- 251 &, $620^{\star \star}$ &,- 271 &, $679^{\star \star}$ \\
\hline DY 2.Çocuk & & & 1 &,- 197 & $690^{\star \star}$ &,- 159 & $672^{\star \star}$ &,- 212 \\
\hline UY 2. Çocuk & & & & 1 &,- 281 &, $558^{\star \star}$ &,- 244 &, $683^{\star \star}$ \\
\hline DY Baba & & & & & 1 &,- 143 & $807^{\star \star}$ &,- 226 \\
\hline UY Baba & & & & & & 1 &,- 235 &, $783^{\star \star}$ \\
\hline DY Anne & & & & & & & 1 &,- 261 \\
\hline UY Anne & & & & & & & & 1 \\
\hline
\end{tabular}

Çalışmaya katılan aile üyelerinin içinde bulundukları ailenin, iletişim kalıplarını algı düzeyleri arasındaki korelasyonu gösteren tablo 8 incelendiğinde, anne, baba ve çocukların diyalog yönelimi boyutu algıları arasında yüksek düzeyde korelasyon bulunmuştur. Buna göre 1. çocuğun diyalog yönelimi boyutu ile 2. çocuğun diyalog yönelimi boyutu arasından $(r=.837 ; P<.001)$ düzeyinde; 1 . çocuğun diyalog yönelimi boyutu ile babanın diyalog yönelimi boyutu arasında $(r=.710 ; P<.001)$ düzeyinde ve 1 . çocuğun diyalog yönelimi boyutu ile annenin diyalog yönelimi boyutu arasında $(r=.725$; $P<.001$ ) düzeyinde pozitif yönlü yüksek korelasyon olup, 1. çocuğun diyalog yönelimi puanı arttıkça 2. çocuğun, annenin ve babanın da diyalog yönelimi puanı artmaktadır. 2 . çocuğun diyalog yönelimi boyutu ile babanın diyalog yönelimi boyutu arasında $(r=.690$; $P<.001$ ) düzeyinde ve 2 . çocuğun diyalog yönelimi boyutu ile annenin diyalog yönelimi boyutu arasında ( $r=.672 ; P<.001)$ düzeyinde pozitif yönlü yüksek korelasyon olup 2 . çocuğun diyalog yönelimi puanı arttıkça baba ve annenin de diyalog yönelimi puanları 
artmaktadır. Babanın diyalog yönelimi boyutu ile annenin diyalog yönelimi boyutu arasında $(r=.807 ; P<.001)$ düzeyinde pozitif yönlü yüksek korelasyon olup babanın diyalog yönelimi puanı arttıkça annenin de diyalog yönelimi puanı artmaktadır.

1. çocuğun uyum yönelimi boyutu ile 2. çocuğun uyum yönelimi boyutu arasından ( $r=$ .807; $P<.001$ ) düzeyinde; 1 . çocuğun uyum yönelimi boyutu ile babanın uyum yönelimi boyutu arasında $(r=.620 ; P<.001)$ düzeyinde ve 1 . çocuğun uyum yönelimi boyutu ile annenin uyum yönelimi boyutu arasında $(r=.679 ; P<.001)$ düzeyinde pozitif yönlü yüksek korelasyon olup, 1. çocuğun uyum yönelimi puanı arttıkça 2. çocuğun, annenin ve babanın da uyum yönelimi puanı artmaktadır. 2 . çocuğun uyum yönelimi boyutu ile babanın uyum yönelimi boyutu arasında $(r=.558 ; P<.001)$ düzeyinde ve 2 . çocuğun uyum yönelimi boyutu ile annenin uyum yönelimi boyutu arasında $(r=.683 ; P<.001)$ düzeyinde pozitif yönlü yüksek korelasyon olup 2. çocuğun uyum yönelimi puanı arttıkça baba ve annenin de uyum yönelimi puanları artmaktadır. Babanın uyum yönelimi boyutu ile annenin uyum yönelimi boyutu arasında $(r=.783 ; P<.001)$ düzeyinde pozitif yönlü yüksek korelasyon olup babanın uyum yönelimi puanı arttıkça annenin de uyum yönelimi puanı artmaktadır.

Tablo 9: Aile İletişim Kalıpları Ölçeği'nin Alt Boyutlarının Annebaba Çocukluk ve Bugün Algıları Arasındaki İlişkiler

\begin{tabular}{|c|c|c|c|c|c|c|c|c|}
\hline Boyutlar & $\begin{array}{l}\text { DY Baba } \\
\text { Çocukluk }\end{array}$ & $\begin{array}{l}\text { UY Baba } \\
\text { Çocukluk }\end{array}$ & $\begin{array}{c}\text { DY Baba } \\
\text { Şimdi }\end{array}$ & $\begin{array}{c}\text { UY Baba } \\
\text { Şimdi }\end{array}$ & $\begin{array}{l}\text { DY Anne } \\
\text { Çocukluk }\end{array}$ & $\begin{array}{l}\text { UY Anne } \\
\text { Çocukluk }\end{array}$ & $\begin{array}{l}\text { DY Anne } \\
\text { Şimdi }\end{array}$ & $\begin{array}{c}\text { UY Anne } \\
\text { Şimdi }\end{array}$ \\
\hline DY Baba Çocukluk & 1 &,- 108 & $361^{*}$ &,- 108 & $343^{*}$ &,- 107 &, $251^{*}$ &,$- 205^{\star}$ \\
\hline UY Baba Çocukluk & & 1 & ,121 &, $400^{*}$ &,- 142 &, $416^{\star}$ & ,068 &, $281^{\star}$ \\
\hline DY Baba Şimdi & & & 1 &,- 143 & ,223* & 144 &, $807^{\star *}$ &,$- 226^{\star}$ \\
\hline UY Baba Şimdi & & & & 1 & ,013 &, $180^{\star}$ &,$- 235^{\star}$ &, $783^{\star *}$ \\
\hline DY Anne Çocukluk & & & & & 1 &,$- 297^{*}$ & ,335* &,- 019 \\
\hline UY Anne Çocukluk & & & & & & 1 &, $263^{*}$ & ,333* \\
\hline DY Anne Şimdi & & & & & & & 1 &,$- 261^{*}$ \\
\hline UY Anne Şimdi & & & & & & & & 1 \\
\hline
\end{tabular}

*. Correlation is significant at the 0.05 level (2-tailed).

**. Correlation is significant at the 0.01 level (2-tailed)

Çalışmaya katılan anne ve babaların içinde yetiştikleri köken aile ve bugün içinde bulundukları ailelerinin iletişim kalıplarını algılama düzeyleri arasındaki korelasyonun gösteren tablo 9 incelendiğinde, anne ve babaların köken aileleri ile şu an içinde bulundukları ailenin diyalog yönelimi ve uyum yönelimi boyutları arasında orta düzeyde pozitif yönlü korelasyon olduğu bulunmuştur. Buna göre çalışmaya katılan babaların köken ailelerinin diyalog yönelimi boyutu ile şu an içinde bulundukları ailenin diyalog yönelimi boyutu arasinda $(r=.361 ; P<.005)$ düzeyinde, annelerin ise $(r=.335 ; P<.005)$ düzeyinde pozitif korelasyon olup babaların ve annelerin çocukluk dönemi diyalog yönelimi puanları arttıkça şu an içinde bulundukları aileye ilişkin diyalog yönelimi boyutu puanları da artmaktadır. Babaların çocukluk dönemi uyum yönelimi boyutu algıları ile şu an içinde bulundukları ailenin uyum yönelimi boyutu arasında $(r=.400 ; P<.005)$ düzeyinde, annelerin ise $(r=.333 ; P<.005)$ düzeyinde pozitif yönlü korelasyon olup anne ve babaların köken aile uyum yönelimi algısı puanları arttıkça şu an içinde bulundukları aile uyum yönelimi algısı puanları da artmaktadır.

\section{Tartışma ve Sonuç}

Aile üyelerinin iletişim yoluyla bir sosyal gerçeklik yarattıkları göz önüne alındığında, üyelerin davranışlarını koordine etmesi ve grup olarak işlev görebilmesi için, diğer 
aile üyelerinin inançları hakkında en azından biraz öngörüye sahip olması gerekir. Aile iletişim kalıpları ailenin bütün üyeleri tarafından gözlemlenebilen benzer davranışlara neden olsa da her bir üyenin kendi bireysel bir geçmişi ve aile üyeleri dışında yaşamına yön veren bir sosyal dünyası vardır. Bu kapsamda mevcut çalışmada Ritchie ve Fitzpatrick (1990) revize ettikleri Aile İletişim Kalıpları Ölçeği kullanılarak, aile üyelerinin diyalog yönelimi ve uyum yönelimi boyutlarını algılamaları arasındaki ilişki ve ebeveynlerin köken ailelerindeki aile iletişim kalıplarıyla mevcut ailelerindeki iletişim kalıplarını algılamaları arasındaki ilişki incelenmiştir. Ayrıca çalışmada ebeveynlerin geldikleri aile türlerinin mevcut aile türlerine olan yansımalarına bakılmıştır. Literatür incelendiğinde aile üyelerinin aile iletişim kalıbı boyutlarını algılamaları arasındaki ilişkiyi inceleyen sadece, Fitzpatrick'in (1990) Aile İletişim Kalıpları Ölçeği'nin geçerlilik ve güvenirlik çalışmasında ve yine Fitzpatrick ve Ritchie'i (1994) tarafından yapılan aile içi iletişim şemalarını anlamaya yönelik çalışmada rastlanmıștır. Elde edilen bulgular yapılan bu çalışmaların sonuçlarıyla karşılaştırıldığında farklılıklar ve benzerlikler bulunmuştur.

Çocuklar ve ebeveynlerinin aile iletişim kalıpları boyutları arasındaki ilişki incelendiğinde aile üyeleri arasında hem diyalog yöneliminde hem de uyum yöneliminde yüksek düzeyde pozitif yönlü ilişki olduğu bulunmuştur. Bu bulgu Ritchie ve Fitzpatrick'in (1990) çalışmasında elde etmiş oldukları pozitif yönlü düşük ilişkiyle karşılaştığında farklıdır. Mevcut çalışmada çocuklar arasında diyalog yöneliminde ( $r=.837)$ düzeyinde ilişki bulunurken, uyum yöneliminde ise $(r=.807)$ düzeyinde ilişki bulunmuştur. Büyük çocuğun baba ile diyalog yönelimi boyutunda $(r=.710)$ düzeyinde ilişki bulunurken, uyum yöneliminde ise $(r=.620)$ düzeyinde ilişki bulunmuştur. Büyük çocuğun anne ile diyalog yönelimi boyutunda ( $r=.725)$ düzeyinde ilişki bulunurken, uyum yöneliminde ise ( $r=$ .679) düzeyinde ilişki bulunmuştur. Küçük çocuğun baba ile diyalog yönelimi boyutunda $(r=.690)$ düzeyinde ilişki bulunurken, uyum yöneliminde ise $(r=.558)$ düzeyinde ilişki bulunmuştur. Büyük çocuğun anne ile diyalog yönelimi boyutunda $(r=.672)$ düzeyinde ilişki bulunurken, uyum yöneliminde ise $(r=.83)$ düzeyinde ilişki bulunmuștur. Anne ve baba arasında ise diyalog yönelimi boyutunda $(r=.807)$ düzeyinde ilişki bulunurken, uyum yöneliminde ise ( $r=.783$ ) düzeyinde ilişki bulunmuştur. Elde edilen bu bulgular aile üyelerinin iletişim kalıplarını benzer şekilde algıladıklarını özellikle kardeşler arasında daha yüksek oranda benzerliğin olduğunu göstermektedir. Özellikle büyük çocukların aile iletişim kalıplarını algılama şekilleri ebeveynleriyle daha çok uyumluyken, anne babalarında kendi aralarındaki benzerlikleri de artmaktadır. İlişkide düşük düzeydeki farklılaşmaların nedeninin ise çocukların sadece aile üyeleriyle değil sosyal dünyayla da etkileşime geçmelerinin kimlik gelişimlerini etkilemesi ve ebeveyn tutumlarına ilişkin farklı algılar olabilir. Ayrıca ebeveynlerin çocuk yetiştirmeye ilişkin tutumlarının da ilk çocuk ve ikinci çocukta farklılaşma olasılığı buna neden olabilmektedir.

Anne ve babaların köken ailelerinin iletişim kalıpları ile mevcut ailelerinin iletişim kalıplarını algılamaları arasındaki ilişkiye bakıldığında pozitif yönde düşük ilişki olduğu bulunmuştur. Buna göre babaların çocukluk dönemi ve mevcut aile diyalog yönelimi düzeyi arasında ( $r=.361)$ düzeyinde ilişki bulunurken, uyum yönelimi algıları arasında ise $(r=.400)$ düzeyinde düşük ilişki bulunmuştur. Annelerin çocukluk dönemi ve mevcut ailelerinin diyalog yönelimi arasında $(r=.335)$ düzeyinde ilișki bulunurken uyum yöneliminde ise $(r=.333)$ düzeyinde pozitif yönlü düşük ilişki bulunmuştur. $\mathrm{Bu}$ farklılaşmanın temel nedeni ebeveynlerin yeni oluşturdukları ailelerdeki aile iletişim kalıplarını değiştirmiş olmaları olabilir. Ebeveynlerin yaşlarının ilerlemiş olması köken ailelerinin iletişim kalıplarını hatırlamaları ve yorumlamaları noktasında engel olmuş 
olabilir veya kendi iletișim șekillerini ebeveynlerinden daha olumlu görüyor olabilirler.

Katılımcıların aile türü algılarına bakıldığında büyük çocukların 64 tanesi ailesini çoğulcu görürken 53'ü koruyucu, 41 fikir birliğine dayalı ve 18'i ise serbesiyetçi, küçük çocukların 66'sı aile türünü çoğulcu, 58'i koruyucu, 32'si fikir birliğine dayalı ve 20'si ise serbesiyetçi olarak görmüştür. İki çocuğun aile türü algıları birlikte değerlendirildiğinde 52 kardeşin ailesini benzer şekilde çoğulcu, 42 kardeşin koruyucu, 25 kardeşin fikir birliğine dayalı ve 9 kardeşin ise serbesiyetçi olarak tanımladığı görülmüştür. Çalışmaya katılan babaların 75'i mevcut aile türünü çoğulcu görürken, 51'i koruyucu, 28'i fikir birliğine dayalı ve 22'si ise serbesiyetçi olarak tanımlamıştır. Çalışmaya katılan annelerin ise 72'si aile türünü çoğulcu tanımlarken, 52'si koruyucu, 28'i fikir birliğine dayalı 24'ü ise serbesiyetçi olarak tanımlamıştır. Anne ve babalar birlikte değerlendirildiğinde 58'i benzer şekilde ailesini çoğulcu tanımlarken 34'ü koruyucu, 16'sı fikir birliğine dayalı ve 16'sı ise serbesiyetçi olarak tanımlamıştır. Ebeveynler ve çocuklar birlikte değerlendirildiğinde hem çocukların hem de ebeveynlerin 86'sı (\%48.86) aile türünü aynı şekilde tanımlamıştır. Önemli sonuçlardan birisi de 29 (\%16.47) ailede anne, baba ve çocukların ortak bir aile türü belirleyememiş olmasıdır. Bunun yanında çalışmaya katılan 22 ailenin çocukları ortak bir aile türü belirlerken bu çocukların ebeveynleri aile türü konusunda farklılaşmışlardır. 18 ailede anne babalar ortak bir aile türü belirtirken çocuklar bir birinden farklı aile türü belirtmişlerdir. 21 ailede ise çocuklar kendi aralarında ebeveynler ise kendi aralarında ama gruplar birbirinden farklı olacak şekilde aile tipi tanımlamıştır. $\mathrm{Bu}$ bulgular aile iletişim kalıplarının ailede işlediğini ve büyük oranda üyelerin benzer aile türü algıladıklarını göstermektedir. Aile üyelerinin benzer şekilde aile türü tanımlaması, aileye etkileşim yaklaşımıyla bir sitem çerçevesinde yaklaşımın önemli veriler sağlayacağını göstermektedir.

Çalışmanın bir diğer önemli bulgusu ise ebeveynlerin köken aile türleri ile mevcut aile türlerinin karşılaştırılmasıyla elde edilmiştir. Buna göre babaların 62'si çocukluk dönemi ailesini çoğulcu, 58'i koruyucu, 28'i fikir birliğine dayalı 28'i ise serbesiyetçi olarak algılamıştır. Babaların 40'ı hem çocukluk hem de mevcut ailelerini çoğulcu olarak tanımlarken, 28'i koruyucu, 11'i fikir birliğine dayalı ve 12'si serbesiyetçi olarak tanımlamıştır. Mevcut ailesini çoğulcu gören babaların 21 tanesi çocukluk dönemi aile tipini koruyucu olarak tanımlarken, çocukluk dönemi aile türünü çoğulcu olarak tanımlayan babaların ise 10 tanesi mevcut aile türünü koruyucu olarak tanımlamıştır. Çalışmaya katılan annelerin ise 59'u çocukluk aile türünü çoğulcu, 77'si koruyucu, 21'i fikir birliğine dayalı ve 19'u ise çocukluk dönemi aile türünü serbesiyetçi olarak tanımlamıştır. Çalışmaya katılan annelerin 34'ü hem çocukluk hem de mevcut aile türünü benzer şekilde çoğulcu, 30'u koruyucu, 7'si fikir birliğine dayalı ve 9'u ise serbesiyetçi olarak tanımlamıştır. Mevcut aile türünü çoğulcu olarak tanımlayan 72 annenin 30 tanesi çocukluk dönemi aile türünü koruyucu olarak tanımlarken, aksine çocukluk dönemi aile türünü çoğulcu olarak tanımlayan 59 annenin sadece 8'i mevcut aile türünü koruyucu olarak tanımlamıştır. Bulgular birlikte değerlendirildiğinde çocukluk dönemi aile türünün büyük oranda mevcut aile türüne aktarıldığı görülmekle birlikte koruyucu aile türü algısının mevcut ailelerde daha azaldığı buna karşın çocukluk döneminde ise ebeveynlerin köken ailelerini daha fazla koruyucu algıladıkları bulunmuştur.

Çalışmadan elde edilen bulgulardan bir diğeri ise anne ve babaların çocukluk döneminde sahip oldukları benzer aile türünün mevcut ailelerinde nasıl sürdügü ile ilişkili bulgulardır. Buna göre çalışmaya katılan 50 (28.41\%) çiftin çocukluk dönemi aile türü algısı aynı olup bu çiftler mevcut ailelerini de aynı türde tanımlamışlardır. Bu 50 çiftin 
26'sı köken ailesini çoğulcu olarak tanımlamış ve mevcut ailesini de çoğulcu olarak tanımlamıştır. Benzer şekilde 14 çift çocukluk dönemi ve mevcut ailesini koruyucu olarak tanımlamış, 5 çift çocukluk ve mevcut ailesini fikir birliğine dayalı tanımlarken benzer şekilde 5 çift ise hem çocukluk hem de mevcut ailesini serbesiyetçi olarak tanımlamıştır. Çalışmaya katılan 28 çift ise çocukluk döneminde benzer aile tipi tanımlamış olmalarına karşın mevcut aile tiplerini değiştirerek yeni bir aile tipi oluşturmuşlardır. Bu grupta yer alan 14 çift köken aile türlerini koruyucu olarak tanımlarken mevcut ailelerini dönüştürerek çoğulcu olarak tanımlamıştır ki bu 14 çiftin çocuklarının büyük bölümü de ebeveynlerine benzer şekilde ailelerini çoğulcu tanımlamıştır. Köken ailesini çoğulcu olarak tanımlayan 4 çift ise mevcut ailesini koruyucu olarak belirtmiştir. Farklı aile türlerinden geldiğini belirten 43 çift mevcut ailelerini ise benzer şekilde tanımlayarak ortak bir iletişim kalıbı yaratmıştır. Bunun aksine farklı aile türlerinden gelen 30 çift ise mevcut aile türlerinin tanımlamasında yine farklılaşmışlardır. Veriler bütünsel olarak, çiftlerin benzer köken ailelerinden gelmeleri durumunda yeni aile iletişim kalıpları oluşturmada daha az zorlandıklarını ve çiftlerin büyük oranda köken ailelerine benzer türde aileler inşa ettiklerini göstermektedir. Aile iletişim kalıbı boyutlarının aile üyeleri tarafından algılanması arasındaki ilişkinin incelendiği çalışmada, aile üyeleri arasında yüksek düzeyde ilişki olduğu ve aile üyelerinin aile türünü benzer şekilde tanımladıkları ve mevcut aile türlerinin özellikle benzer aile türünden gelen çiftlerde yine aynı şekilde sürdürüldüğü görülmüştür. Bu da bize aile iletişim kalıplarına yönelik çalışmaların, aile etkileşimini ve iletişimini anlamamızda çok önemli katkılar sağladığını göstermektedir. Bunun yanında, özellikle farklı köken ailelerden gelen ve ortak bir aile türüne ulaşamayan çiftlerin, daha fazla çatışma yaşayan ve evlilik doyumu düşük olan aileler olup olmadıklarının yeni araştırmalarla incelenmesi önemlidir. Benzer şekilde farklı köken ailelerden gelen çiftlerin yeni kültürü inșa ederken hangi değişkenlerin etkili olduğunun incelenmesi de önemlidir.

\section{Kaynakça}

Baxter, L. A., Braithwaite, D. O., Golish, T. D., \& Olson, L. N. (2002). Contradictions of interaction for wives of husbands with adult dementia. Journal of Applied Communication Research, 29, 221-247. doi: 10.1080/00909880216576

Broderick, C. B. (1993). Understandingfamily processes: Basics of family systems theory. Newbury Park, CA: Sage.

Burgess, E. W, \& Locke, H. (1953). The family. New York: American Book.

Erdogan, Ö., Anık, C., (2018). Aile iletişim kalıpları ölçeğinin Türkçe formunun geçerlilik ve güvenirlik çalışması, Türkiye İletişim Araştırmaları Dergisi, 29, 21-46. doi: $10.17829 /$ maruid. 340460

Fitzpatrick, M.A., \& Ritchie, L. D. (1994). Communication schemata within the family: Multiple perspectives on family interaction. Human Communication Research, 20, 275-301. doi: 10.1111/j.1468-2958.1994.tb00324.x

Galvin, K. M., Dickson, F. C., \& Marrow, S. K. (2006). Systems theory: Patterns and (w)holes in family communication. In D. O. Braithwaite \& L. A. Baxter (Ed.), Engaging theories in family communication: Multiple perspectives (s. 309-324). Thousand Oaks, CA: Sage

Galvin, K. M., Bylund, C. L., \& Brommel, B. J. (2016). Family communication: cohesion and change. (9. bs.) Routledge, New York. 
Hood, B., (2012). The Self Illusion: How the Social Brain Creates Identity. Oxford University Press, Oxford.

Koerner, A. F., \& Fitzpatrick, M. A. ( 1997). Family type and conflict: The impact of conversation orientation and conformity orientation of conflict in the family. Communication Studies, 48, 59-75. doi: 10.1080/10510979709368491

Koerner, A. F., \& Fitzpatrick, M. A. (2002). Nonverbal communication and marital adjustment and satisfaction: The role of decoding relationship relevant and relationship irrelevant affect. Communication Monographs, 69, 33-51. doi: $10.1080 / 03637750216537$

Koerner, A. F., \& Fitzpatrick, M. A. (2004). Communication in intact families. In A. L. Vangelisti (Ed.), LEA's communication series. Handbook of family communication (s. 177-195). Mahwah, NJ, US: Lawrence Erlbaum Associates Publishers.

Mead, G. H., (1972). Mind, self and society: from the standpoint a social behaviorist. Charles W Morris. (ed.). Chicago: The University of Chigago Press.

McLeod, J. M., \& Chaffee, S. H. (1972). The construction of social reality. In J. Tedeschi (Ed.), The social influence process (s. 50-59). Chicago: Aldine-Atherton.

Reiss, D. (1981). The family's construction of reality. Cambridge, MA: Harvard University Press.

Ritchie, D. L. (1991). Family communication patterns. Communication Research, 18, 548565. Doi: $10.1177 / 009365091018004005$

Ritchie, D. L. (1997). Parents' workplace experiences and family communication patterns. Communication Research, 24, 175-187. doi: 10.1177/009365097024002004

Ritchie, D. L., \& Fitzpatrick, M.A. (1990). Family communication patterns: Measuring intrapersonal perceptions of interpersonal relationships. Communication Research, 17, 523-544. doi: 10.1177/009365090017004007

Segrin, C, \& Flora, J. (2005). Family communication. Mahwah, new jersey. Lawrence Erlbaum associates Inc.

Shotter, J. (1993). Conversational realities: The construction of life through language. Newbury Park, CA: Sage.

Steinmetz, S. K. (1999). Adolescence in contemporary families. In M. B. Sussman, S. K. Steinmetz \& G. W Peterson (Ed.), Handbook of marriage and family (s. 307-326). New York: Plenum.

Watzlawick, P., Beavin, J., \& Jackson, D. D. (1967). Pragmatics of human communication. New York, NY: W. W. Norton.

Whitchurch, G. C., \& Dickson, F. C. (1999). Family communication. In M. B. Sussman, S. K. Steinmetz, \& G. W Peterson (Ed.), Handbook of marriage and the family, 2. bs. (s.687-704). New York: Plenum. 


\title{
Relationship Between Family Members' Perceptions of Family Communication Patterns
}

\author{
Ömer Erdoğan (Ph.D.)
}

\section{Extended Abstract}

When communication is considered as a relational process in which individuals create, share and construct meaning (Segrin, Flora, 2005; p. 15), families create their own symbolic worlds of meaning as their unique sub-culture (Whitchurch, Dickson, 1999; p. 688), and only participants of that sub-culture understand this world of meaning. So families create their social reality through communication and the joint actions of family members contribute to the development of special relational realities reflected in family's unique relations, ensuing the formation of communication patterns. According to Baxter and Braithwaite (2002), families construct their social reality and the meanings that regulate it by means of communicative practices (p. 94).

Ritchie (1991), based on the work of McLeod and Chaffee, divides the family communication patterns into two dimensions: conformity-oriented and conversationoriented. Conversation-oriented dimension is defined as an environment where families and all family members have an uninterrupted interaction with a wide range of issues, confronting conflicts, as well as open and communicative sharing between parents, encouraging independence and autonomy. Conformity-oriented dimension indicates the degree of emphasis on the homogeneity of attitudes, values and beliefs in family communication (Fitzpatrick, Ritchie, 1994, p. 296-297). In addition to having direct effects on family communication, the dimensions of conformity and conversation orientation interact with each other and form four qualitatively different family types. According to Fitzpatrick and Ritchie's (1994) classification, families with high scores in terms of conversation orientation and conformity orientation are called Consensual families. The families who scored high in conversation orientation but received low scores in conformity orientation are called Pluralistic families. The families who scored low in conversation orientation, but scored high in conformity orientation are called Protective family. Families with low scores in both conversation and conformity orientation are called Laissez-Faire families.

In order to survive as functioning social systems, families need to create a common social reality and coordinate most of their behavior. This requires them to make reasonably accurate predictions about how they behave and how they communicate. Family cannot function without family members' ability to predict the behavior of others and their reactions to said behavior (Koerner, Fitzpatrick, 2004; p. 182). This necessitates a convergence of family members to perceive existing family communication patterns. Misinterpretation of family communication patterns may lead to the lack of coordination between family members and emergence of non-functional behaviors.

\section{Method}

\section{Sampling}

A total of 704 participants from 176 families participated in the study in 2018-2019. Parents live together as a mother, father and two children. Participants were selected from couples who have been married for at least 15 years. Children participating in the 
study were at least 12 years old, have not been separated from the family and still lived with their family.

\section{Materials}

Family Communication Pattern Scale (FCPS): Family communication patterns of the participants will be assessed through the Revised Family Communication Pattern Scale by Ritchie and Fitzpatrick (1990). The scale consists of two dimensions, which emphasize the level of conformity and conversation among the family members. The FCPS consists of 26 questions, the first 15 items cover conversation orientation and the remaining 11 items cover conformity orientation. The scale items were rated using the 5-point Likert response format, which varied from "strongly disagree" (1) to "strongly agree" (5). The expression of scale items is appropriately expressed without altering the contents of the substances in order to determine the communication patterns of the current families of the parents.

\section{Results}

When the family type perceptions of the parents participating in the study were examined, 72 (40.09) of the mothers and 75 (42.6) of the fathers defined their family as pluralistic, 52 (29.5) of the mothers and 51 (29.0) of the fathers defined their family as protective, 28 (15.9) of the mothers and 28 (15.9) of the fathers defined their family as consensual and 24 (13.6) of the mothers and 22 (12.5) of the fathers defined their family as laissez-faire family. When the family type perceptions of the children participating in the study were examined, 64 (36.4) of the first children and 66 (37.5) of the second children defined their family as pluralistic, 53 (30.1) of the first children and 58 (33.0) of the second children defined their family as protective, 41 (23.3) of the first children and 32 (18.2) of the second children defined their family as consensual and 18 (10.2) of the first children and 20 (11.4) of the second children defined their family as laissez-faire family.

When examining how fathers defined their childhood period family and their current family as illustrated in Table 5, it was determined that 75 (42.6) of the fathers defined their current family as pluralistic, 51 (29.0) of the fathers defined their current family as protective, 28 (15.9) of the fathers defined their current family as consensual and 22 (12.5) of the fathers defined their current family as laissez-faire family. While defining their childhood family, 62 (35.2) of the fathers defined their childhood family as pluralistic, 58 (33.0) defined their childhood family as protective, 28 (15.9) defined their childhood family as consensual and 28 (15.9) defined their childhood family as laissez-faire family. When examining how mothers defined their childhood period family and their current family as illustrated in Table 6, it was determined that 72 (40.9) of the mothers defined their current family as pluralistic, 52 (29.5) of the mothers defined their current family as protective, 28 (15.9) of the mothers defined their current family as consensual and 24 (13.6) of the mothers defined their current family as laissez-faire family. While defining their childhood family, 59 (33.5) of the mothers defined their childhood family as pluralistic, 77 (43.8) defined their childhood family as protective, 21 (11.9) defined their childhood family as consensual and 19 (10.8) defined their childhood family as laissez-faire family.

While examining the family types for parents and children together as illustrated in Table 7, it was determined that in 86 (48.86) families, both parents and children defined the same family type. Parents of 125 (71.02) families participating in the study defined the same family type and children in 129 (73.30) families defined the same family type. In 
29 (16.48) out of 90 (51.14) families where parents and children did not share a decision on family type, none of the family members defined the same type, while in 39 (22.16) families, parents defined the same family type and in 43 (24.43) families, children defined the same family type.

When examining the correlation between the family members and the level of perception of the communication patterns of the family members who participated in the study, a high correlation was found between the perceptions of the conversation orientation of the parents and children, as illustrated in Table 8. According to that there is a high positive correlation between conversation orientation of the first and second child $(\mathrm{r}=$ ,837; $\mathrm{P}<.001$ ), as well as between conversation orientation of the first child and father $(\mathrm{r}=, 710 ; \mathrm{P}<.001)$ and between conversation orientation of the first child and mother $(\mathrm{r}=, 725 ; \mathrm{P}<.001)$. As the conversation orientation score of the first child increases, the conversation orientation scores of the second child, mother and father also increase. There is a high positive correlation between conversation orientation of the second child and father $(\mathrm{r}=, 690 ; \mathrm{P}<.001)$ and between conversation orientation of the second child and mother $(\mathrm{r}=, 672 ; \mathrm{P}<.001)$. As the conversation orientation score of the second child increases, the conversation orientation scores of mother and father also increase. There is a high positive correlation between father's conversation orientation and mother's conversation orientation $(\mathrm{r}=, 807 ; \mathrm{P}<.001)$. As father's conversation orientation score increases, mother's conversation orientation score increases as well.

There is a high positive correlation between conformity orientation of the first and second child ( $\mathrm{r}=, 807 ; \mathrm{P}<.001)$, as well as between conformity orientation of the first child and father $(\mathrm{r}=, 620 ; \mathrm{P}<.001)$ and between conformity orientation of the first child and mother $(\mathrm{r}=, 679 ; \mathrm{P}<.001)$. As the conformity orientation score of the first child increases, the conformity orientation scores of the second child, mother and father also increases. There is a high positive correlation between conformity orientation of the second child and father $(\mathrm{r}=, 558 ; \mathrm{P}<.001)$ and between conformity orientation of the second child and mother $(\mathrm{r}=, 683 ; \mathrm{P}<.001)$. As the conformity orientation score of the second child increases, the conformity orientation scores of mother and father also increase. There is a high positive correlation between father's conformity orientation and mother's conformity orientation $(\mathrm{r}=, 783$; $\mathrm{P}<.001)$. As father's conformity orientation score increases, mother's conformity orientation score increases as well.

\section{Discussion and Conclusion}

In this context, using Ritchie and Fitzpatrick (1990) Revised Family Communication Patterns Scale, the relationship between family members' perceptions of conversation orientation and conformity orientation dimensions and the relationship between the parents' perception of family communication patterns in the origin families and their communication patterns in their current families were examined. In addition, the researcher examined the reflections of the family types of the parents on the current family types. Literature review reveals that the relationship between family members' perceptions of family communication patterns is examined only in the study of the validity and reliability of Ritchie and Fitzpatrick's (1990) Family Communication Patterns Scale and the study of intrafamily communication schemes by Fitzpatrick and Ritchie (1994). Differences and similarities were found when the findings were compared with the results of those studies.

When the research examined the relationship between the dimensions of family 
communication patterns of children and their parents, it was found that there was a high positive correlation between family members both in conversation and conformity orientations. This finding is different in comparison to Ritchie and Fitzpatrick's (1990) findings regarding a low positive correlation. These findings show that family members perceive communication patterns in a similar way, and that there is a higher degree of similarity between siblings. Specifically, the perception of family communication patterns by older children is more compatible with their parents, while similarities between their parents increase as well. The reason for the low level of differentiation in the relationship may be that the interaction of children with the social world and not only with their family members affects their identity development, as well as different perceptions about parental attitudes. In addition, the possibility of difference in parents' attitudes towards child raising between the first and the second child may be the reason as well.

Low positive correlation between family communication patterns of the parents' origin family and the perception of their current family communication patterns was discovered. The main reason for this difference may be that parents have changed their family communication patterns in their newly formed families. The advanced age of the parents may have prevented them from recalling and interpreting the communication patterns of their origin families, or they may consider their own communication styles more positive than those of their parents.

When the family type perceptions of the participants were examined, it was determined that 64 of the first children defined their family as Pluralistic, 53 of the first children defined their family as Protective, 41 of the first children defined their family as Consensual and 18 of the first children defined their family as Laissez-Faire family, while 66 of the second children defined their family as Pluralistic, 58 of the second children defined their family as Protective, 32 of the second children defined their family as Consensual and 20 of the second children defined their family as Laissez-Faire family. When the family type perceptions of children were examined, it was determined that 52 siblings defined their family as Pluralistic, 42 siblings defined their family as Protective, 25 siblings defined their family as Consensual and 9 siblings defined their family as Laissez-Faire family. 75 of the fathers defined their family as Pluralistic, 51 of the fathers defined their family as Protective, 28 of the fathers defined their family as Consensual and 22 of the fathers defined their family as Laissez-Faire family. 72 of the mothers defined their family as Pluralistic, 52 of the mothers defined their family as Protective, 28 of the mothers defined their family as Consensual and 24 of the mothers defined their family as Laissez-Faire family. When parents were examined together, 58 defined their family as Pluralistic, 34 defined their family as Protective, 16 defined their current family as Consensual and 16 defined their current family as Laissez-Faire family. When parents were examined together with their children, it was determined that in 86 (48.86) families, both parents and children defined the same family type. It is a significant finding that in 29 (16.47) families, none of the family members defined the same family type. In addition to that, the children of 22 families were able to define a common family type that was different from the family type defined by their parents. In 18 families, parents were able to define a common family type while children define different types. In 21 families, siblings defined the same family type and parents defined the same family type, different from their children's choices. These findings show that family communication patterns work in family and that family members mostly perceive a similar family type. Similarly, family type identification of family members shows that within the framework of a system 
with an interaction approach to the family, the approach will provide important data.

Another finding resulting from this study is how similar family type of the parents from their childhood period is continued in their current families. According to that, the childhood family type perception of 50 (28.41) couples participating in the study was the same and these couples defined their current family types as the same type. 26 out of these 50 couples defined their origin family and their current family as pluralistic. Similarly, 14 couples defined their childhood families and their current families as protective, while 5 couples defined their origin and current families as consensual and 5 couples defined their origin and current families as laissez-faire family. 28 couples participating in the study defined their current family type as different from their childhood family type. 14 couples in this group defined their origin family as protective while transforming and defining their current family as pluralistic. Majority of the children of these 14 couples similarly defined their families as pluralistic. 4 couples who defined their origin family as pluralistic defined their current family as protective. 43 couples who indicated that they come from a different family type also created a common communication pattern by similar definition. On the other hand, 30 couples who indicated that they come from a different family type made different definitions of their current family. The data as a whole indicate that couples struggle less to create new family communication patterns if couples come from similar families of origin, and that couples mostly form families of similar types as their origin families. In this study, which examined the relationship between family members' perception of family communication pattern, it is evident that there is a strong relationship between the family members, that family members define the family type in a similar way and the existing family types were maintained in the same way in the couples from the similar family type. This shows us that the studies on family communication patterns provide significant contributions to our understanding of family interaction and communication. In addition, further research is required to examine whether couples who come from different origin families and who do not have a common family type, are more likely to have families who experience more conflicts and have low marriage satisfaction. Similarly, it is also important to examine which variables are effective in building a new culture for couples from different origin families.

Keywords: Family Communication Patterns, Family Communication, Conformity Dimension, Conversation Dimension. 
